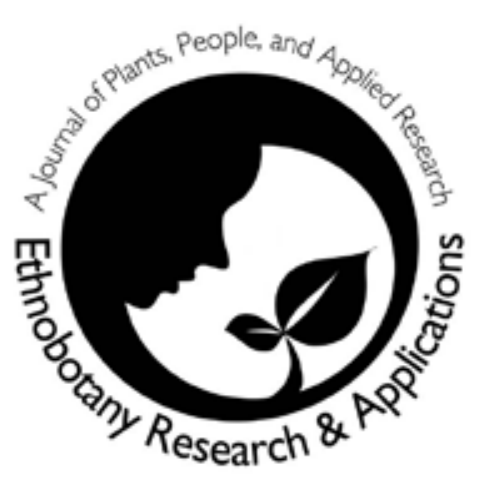

\title{
Ethnobotany of the Genus Artemisia L. (Asteraceae) in Pakistan
}

\author{
Muhammad Qasim Hayat, Mir Ajab Khan, \\ Muhammad Ashraf and Shazia Jabeen
}

\section{Research}

\begin{abstract}
Pakistan hosts rich biodiversity, including 38 species of the genus Artemisia L. (Asteraceae). Plant morphological descriptions were noted by means of observations and ethnobotanical details were documented through questionnaires and meetings, with herbalists and local inhabitants. Twelve Artemisia species are popularly used among Pakistani people as food, ornaments, fumigants and medicines. These are Artemisia absinthium L., Artemisia annua L., Artemisia brevifolia Wall. ex DC., Artemisia dracunculus L., Artemisia dubia Wall. ex Besser, Artemisia herba-alba Asso., Artemisia japonica Thunb., Artemisia maritima L. Ex Hook.f., Artemisia roxburghiana Wall. ex Besser, Artemisia santolinifolia Turcz. ex Krasch., Artemisia scoparia Waldst. \& Kit., and Artemisia vulgaris L.
\end{abstract}

\section{Introduction}

Artemisia L. is a large, diverse and economically important genus of the family Asteraceae. It has more then 500 species (the number fluctuate depending on authors: Bremer \& Humphries 1993, Ling 1982,1991a,b, 1994,1995a,b, Mabberley 1990, McArthur 1979, Oberprieler 2001, Valles \& Garnatge 2005, Valles \& McArthur 2001). Artemisia is a wind pollinated cosmopolitan genus, mainly distributed in temperate areas of mid to high latitudes of the northern hemisphere, colonizing in arid and semiarid environmental landscape, with only a few representatives in the southern hemisphere. Central Asia is its center of diversification, while the Mediterranean region and North West America are two secondary speciation areas (McArthur \& Plummer 1978, Valles \& McArthur 2001). A few species are also reported in Africa and Europe (Ling 1994, Shultz 2006, Tutin et al. 1976). Many species are economically important as medicines, food, forage, ornamentals or soil stabilizers in disturb habitats. Some taxa are toxic or allergenic and some others are invasive weeds which can adversely affect harvests (Pareto 1985, Tan et al. 1998).
Most of the species are perennial with only ten being annuals or biannual (Valles et al. 2003). Artemisia is considered as an indicator of steppe climate (Erdtman 1969) and moderate precipitation (El-Moslimany 1990). Due to high number of species, ecological and economic importance, the genus Artemisia has been the object of a diversity focused studies (Valles et al. 2003).

Artemisia is a taxonomically complex genus because some species have different morphological forms and others closely resemblance each other. These traits make it quiet difficult to correctly identify a sample without detailed morphological review. Artemisia species are mostly herbs, and sometimes shrubs, usually with strong aroma. Plant bodies are often densely hairy. Leaves are pinnatifid to pinnatisect with variable dimensions. Capitulum inflorescence is generally in the form of a paniculate-raceme arrangement. Herbaceous involucral bracts are present. Receptacles are convex or flat and naked or covered by hairs. Ray florets are pistillate. Corolla color is yellow or green and rarely brown. Disk florets are bisexual. Cypselas are obovoid to oblong and mostly brown (Ghafoor 2002).

\section{Correspondence}

Muhammad Qasim Hayat and Mir Ajab Khan, Department of Plant Sciences, Quaid-i-Azam University, Islamabad, PAKISTAN.

mqasimhayat@hotmail.com

Muhammad Ashraf, NUST Center of Virology and Immunology, National University of Science and Technology, Rawalpindi, PAKISTAN.

Shazia Jabeen, National Center of Excellence in Geology, University of Peshawar, Peshawar, PAKISTAN.

Ethnobotany Research \& Applications 7:147-162 (2009)

Published: May 20, 2009 
"Pakistan has great diversity of both climate and terrain ranging from the scorching deserts of Sind, to the relatively moist temperate forest of North West Frontier Province (NWFP). This rich and varied habitat is a home to rich biodiversity" (Nasir \& Rafiq 1995). Presently, 38 species of Artemisia have been identified and botanically reported in Pakistan, mainly in arid and semiarid areas of Boluchistan, NWFP, Northern Punjab and Kashmir forming an important component of Artemisia steppes (Ghafoor 2002). In this research work, we presented various ethnobotanical aspects related to the genus Artemisia in Pakistan.

\section{Methodology}

Field surveys were conducted over a two year period (2006-07) in areas of Pakistan where Artemisia has been reported by previous authors (Ghafoor 2002, Sterwart 1972). Field methods were drawn from Bridges and Lau (2006), Hayat et al. (2008), Jain (1967), Martin (2004),

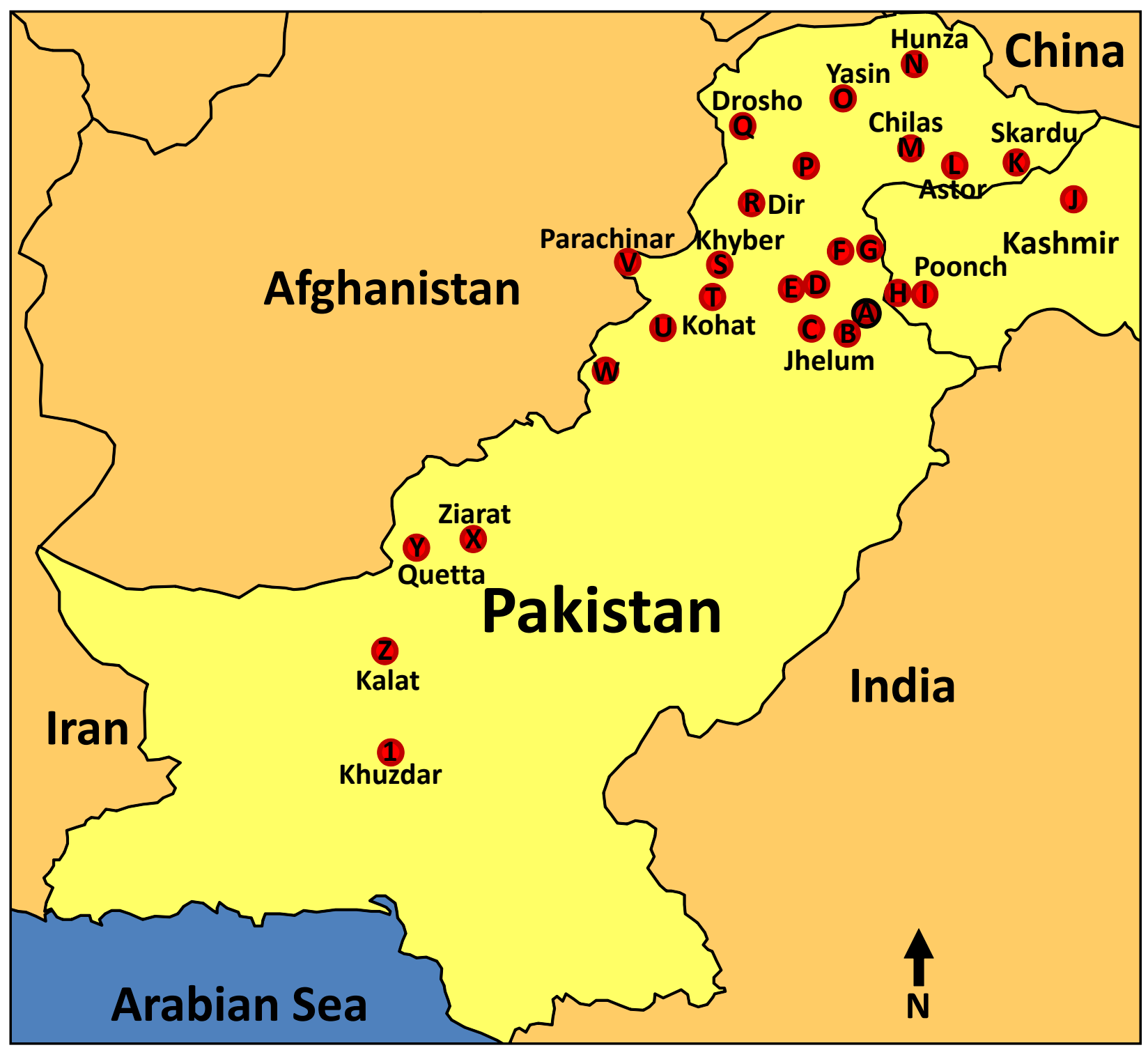

Figure 1. Areas investigated (red dots) for Artemesia throughout Pakistan. (A: Islamabad, Quaid-i-Azam University campus; B: Chakwal, Talagang; C: Jhelum: Rotas fort; D: Rawalpindi, Murree hills; E: Attock, Fatahjang; F: Abbotabad, Galiaat; G: Manshera, Ujtar, Naran to Lalusar lake track; H: Bagh, Suddhen Gali; I: Azad Jammu \& Kashmir: Pearl valley, Mutyal Mara; J: Deosai Plains; K: Skardu; L: Astor, Astor village; M: Chilas, Nagar ; N: Hunza valley; O: Gilgit, Nattar valley; P: Swat, Kalam; Q: Chitral, Ayun; R: Dir, Lowarai pass; S: Peshawar, Sardaryab; T: Kohat, Khadi Zai; U: Karak, Mitha khel; V: Kurram agency, Parachinar; W: Waziristan, Burki; X: Ziarat, Sandman Tangi; Y: Quetta, Hanna Lake; Z: Kalat, Bolan pass; 1: Khuzdar, Khuzdar town) 


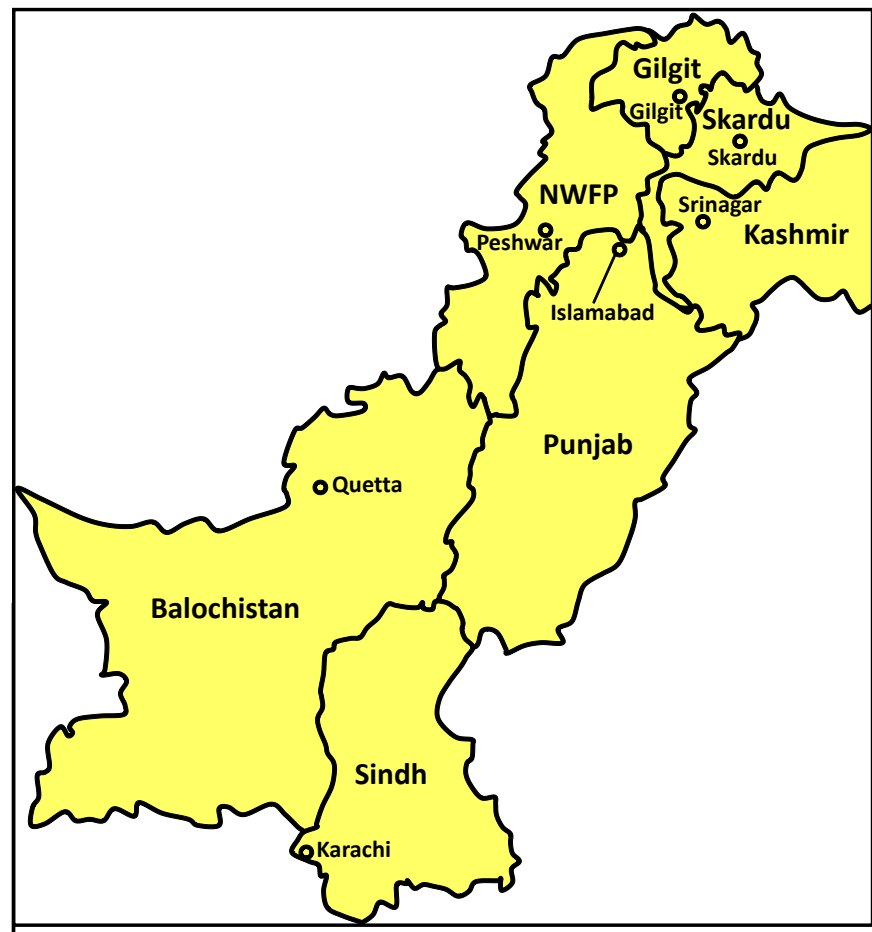

Figure 2 (to left). Provinces and some major cities of Pakistan.

Figure 3 (below). Other locations in Pakistan with Artemisia. A. Astor; B. Attock; C. Azad Jammu; D. Baltistan; E. Chitral; F. Deosai plains; G. Hunza; H. Jhelum; I. Kalat; J. Khagan; K. Khuzdar; L. Kohat; M. Kurram; N. Ladakh; O. Malakand; P. Mansehra; Q. Muzafrabad; R. Parachinar; S. Peshawar; T. Ponch; U. Quetta; V. Rawalpindi; W. Skardu; and X. Swat.

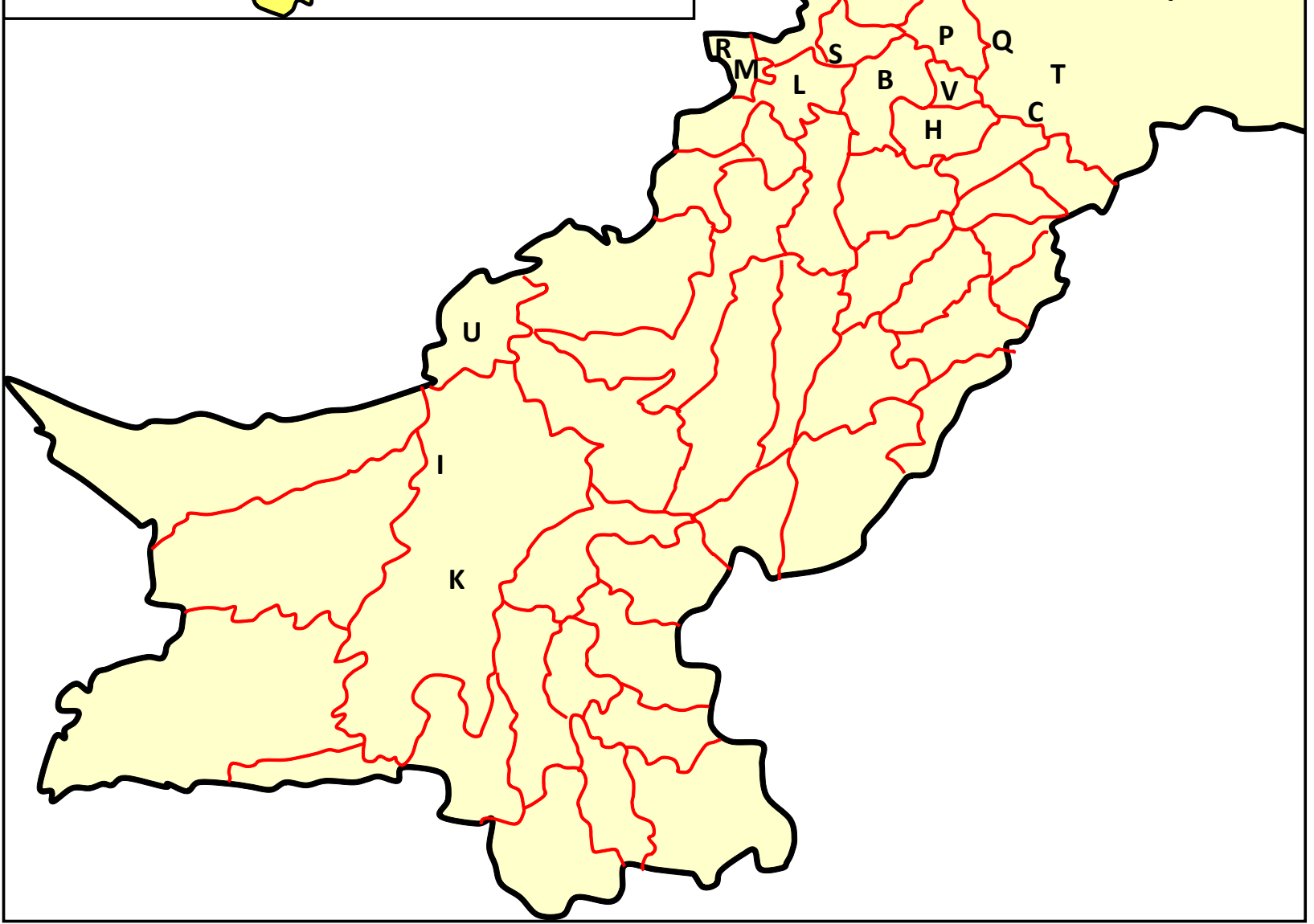


Table 1. List of taxa studied ethnobotanically and their herbarium vouchers. ISL: Herbarium, Quaid-i-Azam University, Islamabad. PUP: Herbarium, University of Peshawar, Peshawar.

\begin{tabular}{|l|l|l|}
\hline Taxon & Collection data & Herbarium voucher \\
\hline A. absinthium L. & Gilgit: Nattar valley. M.Q. Hayat, 2007 & PUP, PH004 (ART004) \\
\hline A. annua L. & Skardu. M.Q. Hayat, 2008 & ISL, 16253 \\
\hline A. brevifolia Wall. ex DC. & $\begin{array}{l}\text { Mansehra: Ujtar, Naran to Lalusar lake track. } \\
\text { M.Q. Hayat, 2007 }\end{array}$ & PUP, PH007 (ART007) \\
\hline A. dracunculus L. & Gilgit: Nattar valley. M.Q. Hayat, 2007 & ISL, 19222 \\
\hline A. dubia Wall. ex Besser & $\begin{array}{l}\text { Rawalpindi: Murree Hills, PLT, Ayubia National Park. } \\
\text { M.Q. Hayat, 2007 }\end{array}$ & PUP, PH002 (ART002) \\
\hline A. herba-alba Asso. & Quetta: Hanna Lake. M.A. Khan, 2007 & ISL, 28615 \\
\hline A. japonica Thunb. & $\begin{array}{l}\text { Rawalpindi: Murree Hills, PLT, Ayubia National Park. } \\
\text { M.Q. Hayat, 2007 }\end{array}$ & PUP, PH008 (ART008) \\
\hline A. maritima I. ex Hook.f. & Kurram Agency. M.Q. Hayat, 2007 & ISL, 92830 \\
\hline A. roxburghiana Wall. ex Besser & $\begin{array}{l}\text { Rawalpindi: Murree Hills, PLT, Ayubia National Park. } \\
\text { M.Q. Hayat, 2007 }\end{array}$ & PUP, PH001 (ART001) \\
\hline A. santolinifolia Turcz. ex Krasch. & Gilgit: Naltar valley. M.Q. Hayat, 2007 & PUP, 239 (1108) \\
\hline A. scoparia Waldst. \& Kit. & $\begin{array}{l}\text { Islamabad: Quaid-i-Azam University campus. } \\
\text { M.Q. Hayat, 2008 }\end{array}$ & ISL, 32313 \\
\hline A. vulgaris L. & $\begin{array}{l}\text { Azad Jammu \& Kashmir: Pearl valley, Mutyal Mara. } \\
\text { M.Q. Hayat, 2008 }\end{array}$ & PUP, PH006 (ART006) \\
\hline
\end{tabular}

Shinwari and Khan (2000), Trotter (1981), and Vogl et al. (2004). Artemisia diversity was surveyed in 43 different localities (Figure 1, Table 1). Plant specimens were collected, identified and described morphologically. The voucher specimens were deposited in Quaid-i-Azam University Islamabad (ISL) and University of Peshawar, Peshawar (PUP) herbaria for future reference (Table 1).

A questionnaire was used to interview the local inhabitants during the field surveys and ethnobotanical information was gathered on Artemisia species which were commonly used in studied localities. Vernacular names, harvesting and processing methods and mode of administration of these plants to treat human ailments along with other uses were noted through the questionnaire. The questionnaire was completed by interviewing informants who were knowledgeable in traditional uses of Artemisia, and are native to the studied areas or have spent most of their lives there. These informants were selected as those recognized as having knowledge by the local community. The conversation was done in local languages (Urdu, Pashto, Shena, Punjabi, Hindco and Kashmiri). Local guides were approached for communication between the local communities and informants. A total of 173 key informants $(66.92 \%$ men and $33.07 \%$ women) between the ages of 50-60 years were interviewed. Repeated queries were made to get the data confirmed.

\section{Results}

In this research work, we have identified twelve Artemisia species which are utilized by local communities of different localities in different ways. Plant descriptions, distributions, part used and folk uses are described below. 1. A. absinthium L. (Vilayati afsantin, Afsantin, Kakamush, Afsantheen, Zoon) (Figure 4)

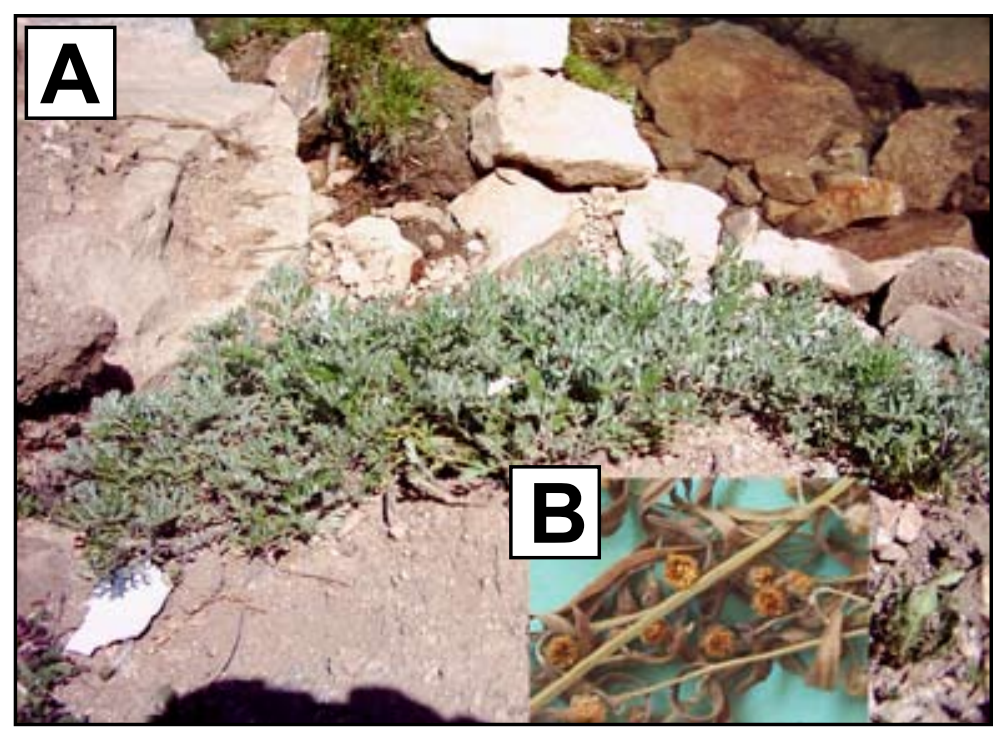

Figure 4. Artemisia absinthium L. (A: Young plants, B: Flowers), Pakistan. 
Phytography: The plant grows mostly in humid soils or near water in rocky terrain with the sandy clay soil. This herb is perennial with 70 to $150 \mathrm{~cm}$ tall hairy stems which are somewhat woody at the base. Petioles of basal leaves are 6 to $12 \mathrm{~cm}$ long. The leaf blade is ovate to elliptic or ovate, 9-12 cm X 7-9 cm, 3-pinnatisect in segments which are pinnately lobed. Lobules are lanceolate-elliptic or linear, 7-15 mm $\times 2-5 \mathrm{~mm}$ with obtuse apex. Petiole of middle cauline leaves is 2 to $6 \mathrm{~cm}$ long. Leaf blade is ovate or elliptic-ovate, 2-pinnatisect. Lobules are linear-lanceolate, $10-20 \mathrm{~mm} \times 3-5 \mathrm{~mm}$. Uppermost leaves are 4-7 cm $X 2-5 \mathrm{~cm}$, pinnatisect and lobed. Leafy bracts are 3-lobed and entire. Globose Capitula have paniculate arrangement which is 3.5 to $4 \mathrm{~mm}$ in diameter with short pedicel. Receptacle is semiglobose and densely hairy. Cypselas are oblong with minute upper crown.

Flowering period: June to September.

Local distribution: Found in Chitral, Skardo, Ladakh, Parachinar and Kurram Agency from 1000 to 3500 m altitude.

Distribution in the world: Afghanistan, China, India, Japan, Kazakstan, Kyrgyzstan, Russia, Europe, North Africa, SW Asia, and North America.

Part Used: Whole Plant, leaves and seeds.
Ethnobotanical uses:

1. The dried plant is used to protect clothes against insects and as an insecticide.

2. The whole plant decoction is used as a tonic for general health.

3. Leaf powder is used for gastric problems and intestinal worms.

4. Seed powder is taken orally to treat rheumatism.

5. Seed powder paste is applied on teeth for pain relief.

\section{A. annua L. (Afsantin, Afsantin jari) (Figure 5)}

Phytography: This herb is annual, up to $190 \mathrm{~cm}$ tall, much branched and with strong aromatic smell. Stems are sparsely hairy. Leaves have punctate glands. Petiole of middle cauline leaves are $1.5-2.5 \mathrm{~cm}$ long. Lowermost cauline leaves are ovate or triangular-ovate, $3.5-6 \mathrm{~cm} \mathrm{X}$ 2.5-6.5 cm. 3-pinnatipartite leaves have 6-10 segments in pairs. lobules are deeply serrate with triangular teeth, $1.5-2 \times 0.5 \mathrm{~mm}$. Mid vein is prominent adaxially. Middle cauline leaves are 2 to 3 pectinatisect. Uppermost leaves and leafy bracts are 2-pinnatipartite. Globose capitula is in a broad pyramidal with paniculate arrangement, which

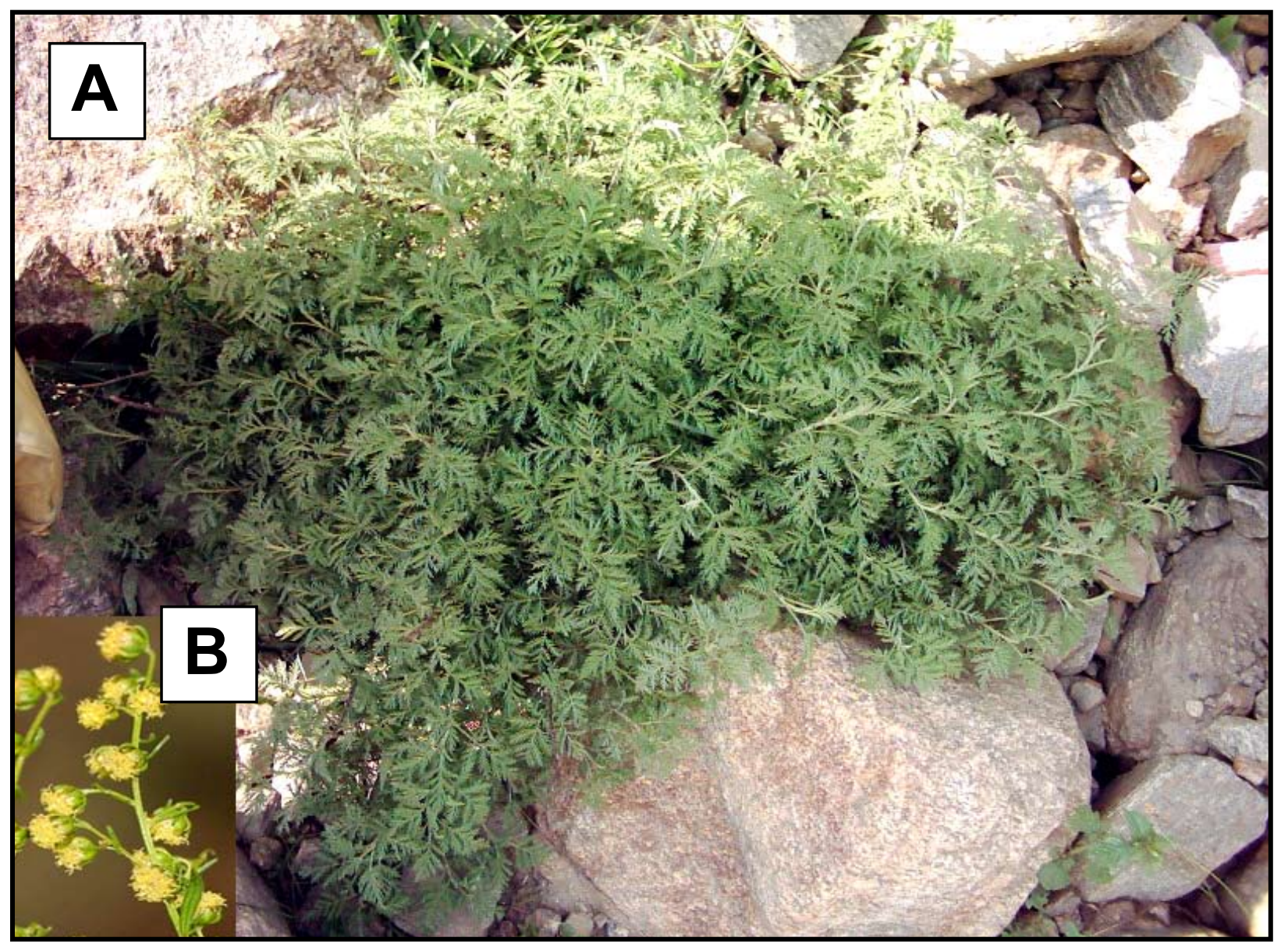

Figure 5. Artemisia annua L. (A: Young plants, B: Flowers), Pakistan. 
is $1.5-2.5 \mathrm{~mm}$ in diameter with nodding and have short pedicels. Ray florets are 10-15 in number and disc florets are 15-25, with dark yellow or yellow color. Cypselas are ellipsoid-ovoid in shape.

Flowering Period: August to September.

Local distribution: Found in Gilgit, Baltistan, Skardu and Kohat from 1493 to 2286 m altitude.

Distribution in the world: Asia, Europe, North Africa, and North America.

Part used: Whole plant.

Ethnobotanical uses:

1. A decoction of the whole plant is used for treatment of Malaria.

2. Leaves are used for fever, cough and common cold.

3. Dry powder of leaves is taken to treat diarrhea.

4. Oil of afsantin is used in local perfumes (ettar) due to its pleasant fragrance.

3. A. brevifolia Wall. ex DC. (Mori, Tarkha, Zoon) (Figure 6 )

Phytography: This woody rooted species grows in stony terrain with sandy soils and low humidity. It covers sun facing slops of dry mountains. The plants are herbs or subshrubs with slight aromatic fragrance. Plant height var- ies from 14-35 cm. Color of whole plant is whitish green. Stems often have a purplish tinge. Lower leaves are petiolate with ovate leaf blades, with 3-pinnatisect segments which are arranged in 2 to 4 pair. Middle cauline leaves are 2-pinnatisect and upper leaves are pinnatisect or entire. Heads are in the form of narrow panicle. Involucral bracts are densely hairy. Florets are 3 to 8 in number. Cypselas are oblong-ovoid to ellipsoid in shape.

Flowering period: August to September.

Local distribution: Found in Chitral, Gilgit, Khaghan, Swat, Baltistan, Astor, Deosai plains and Ladakh above 2500 m altitude.

Distribution in the world: Afghanistan and Northern India.

Part used: Whole plant.

Ethnobotanical uses:

1. The plant extract is used as a vermifuge.

2. The leaves and inflorescence are ground to form powder (phaki) which is used for gastric problems.

3. Dried stems of the plant are used for fire purposes.

\section{A. dracunculus L. (Targoon, Sheni tarkha) (Figure 7)}

Phytography: This plant is a small shrub, $50-200 \mathrm{~cm}$ tall, densely or some time sparsely hairy. Leaves are sessile and sparsely hairy or some time glabrescent in appear-

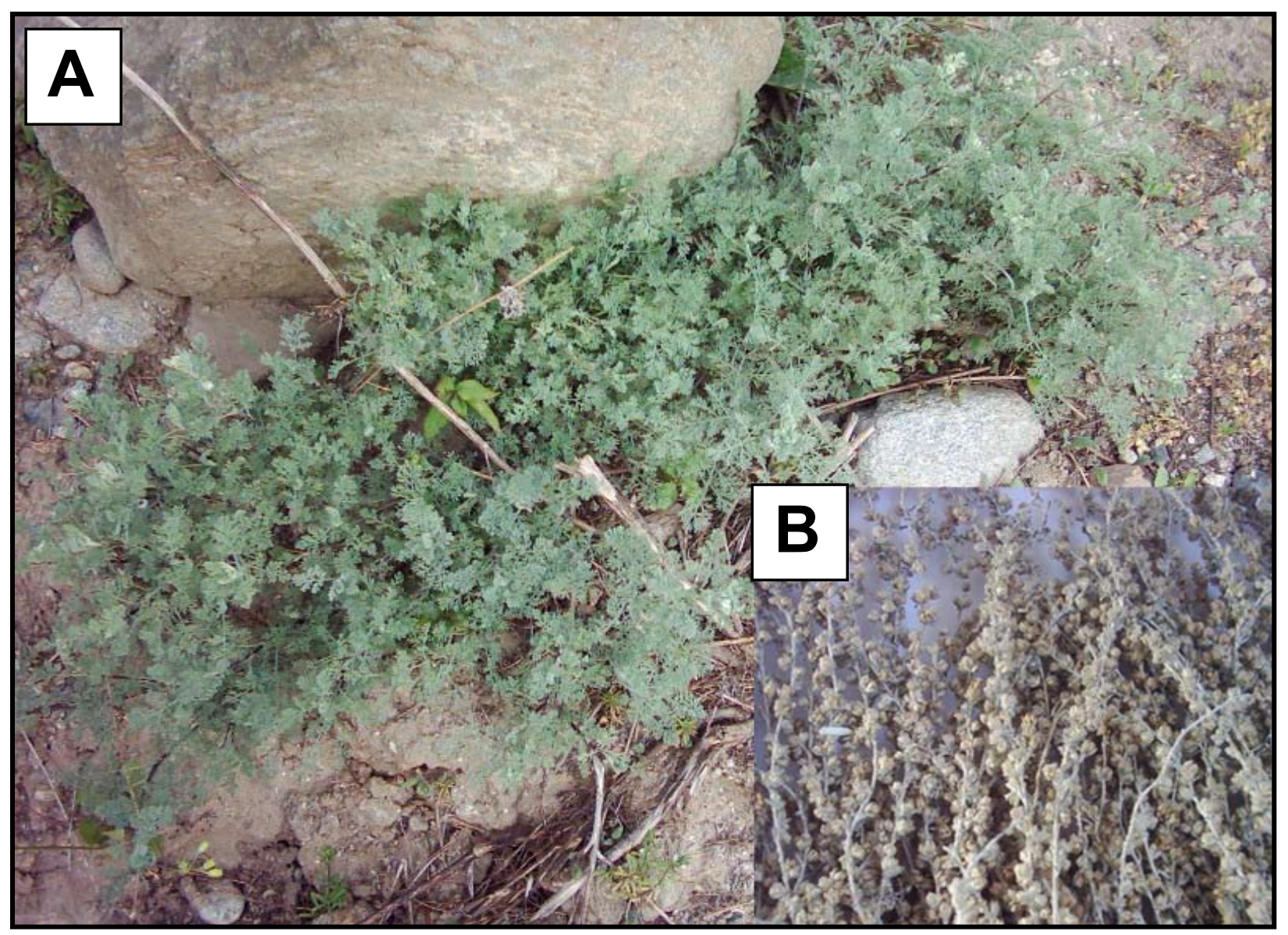

Figure 6. Artemisia brevifolia Wall. ex DC. (A: Young plants, B: Flowers), Pakistan. 
ance. Middle cauline leaves are linear-lanceolate to elliptic-lanceolate, $20-70 \mathrm{~mm} \times 2.5-6$ $\mathrm{mm}, 3$-partite or apartite and cleft apically with small 1 to 2 lateral lobes. Uppermost leaves and leafy bracts are minute, linear to lanceolate, $5.5-25 \mathrm{~cm} \times 1.5-2.5 \mathrm{~mm}$. Subglobose to ovoid capitula in broad panicles and 3-4 $\mathrm{mm}$ in diameter with short pedicels or some times sessile. Involucral bracts are glabrescent. Ray florets are 8-10 in number and disc florets are 5-15 in number. Cypselas are obovoid to obovoid-ellipsoid in shape.

Flowering period: August to September. Local distribution: Found in Chitral, Gilgit and Kashmir, from 3000 to 4000 m altitude.

Distribution in the world: Central \& Western Asia (particularly Afghanistan, North India, Kazakstan, Mongolia, China, Russia, Tajikistan), Central, East \& Western Europe, and North America.

Part used: Leaves.

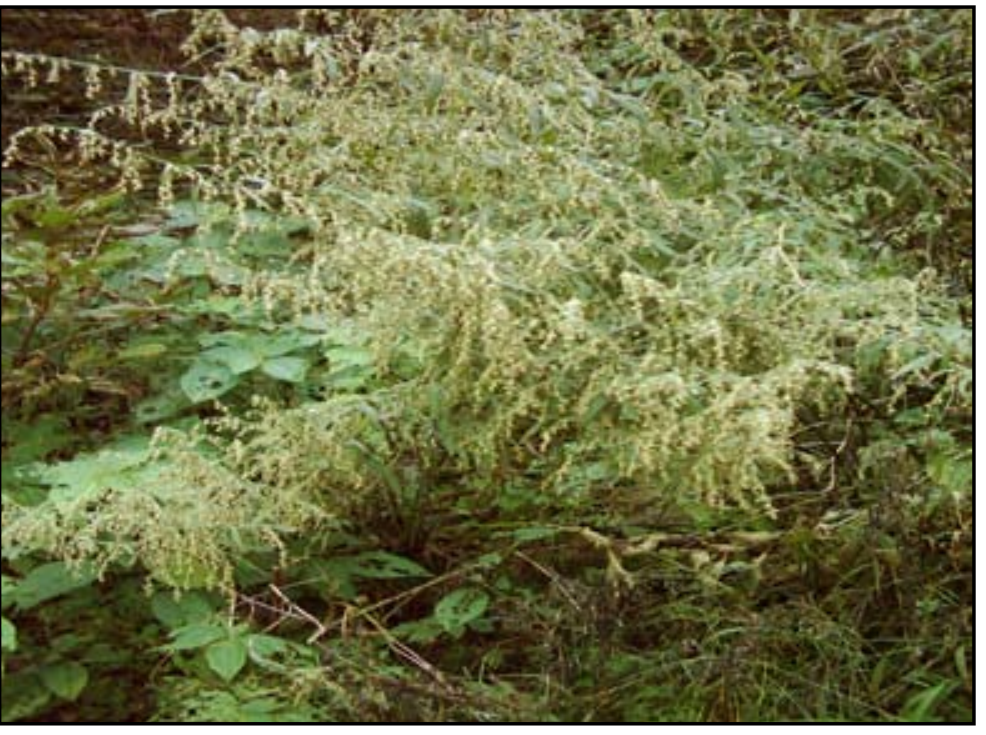

Ethnobotanical uses:

1. Gastronomic herb.

2. Fodder for sheep.

5. A. dubia Wall. ex Besser (Tarkha) (Figure 8)

Figure 7. Artemisia dracunculus L., Pakistan.

Phytography: This species is easily identified from the closely related species by the leaves with many white small dots on the upper surface, categorized as Subshrubs which are $70-110 \mathrm{~cm}$ tall, much branched. Branch-

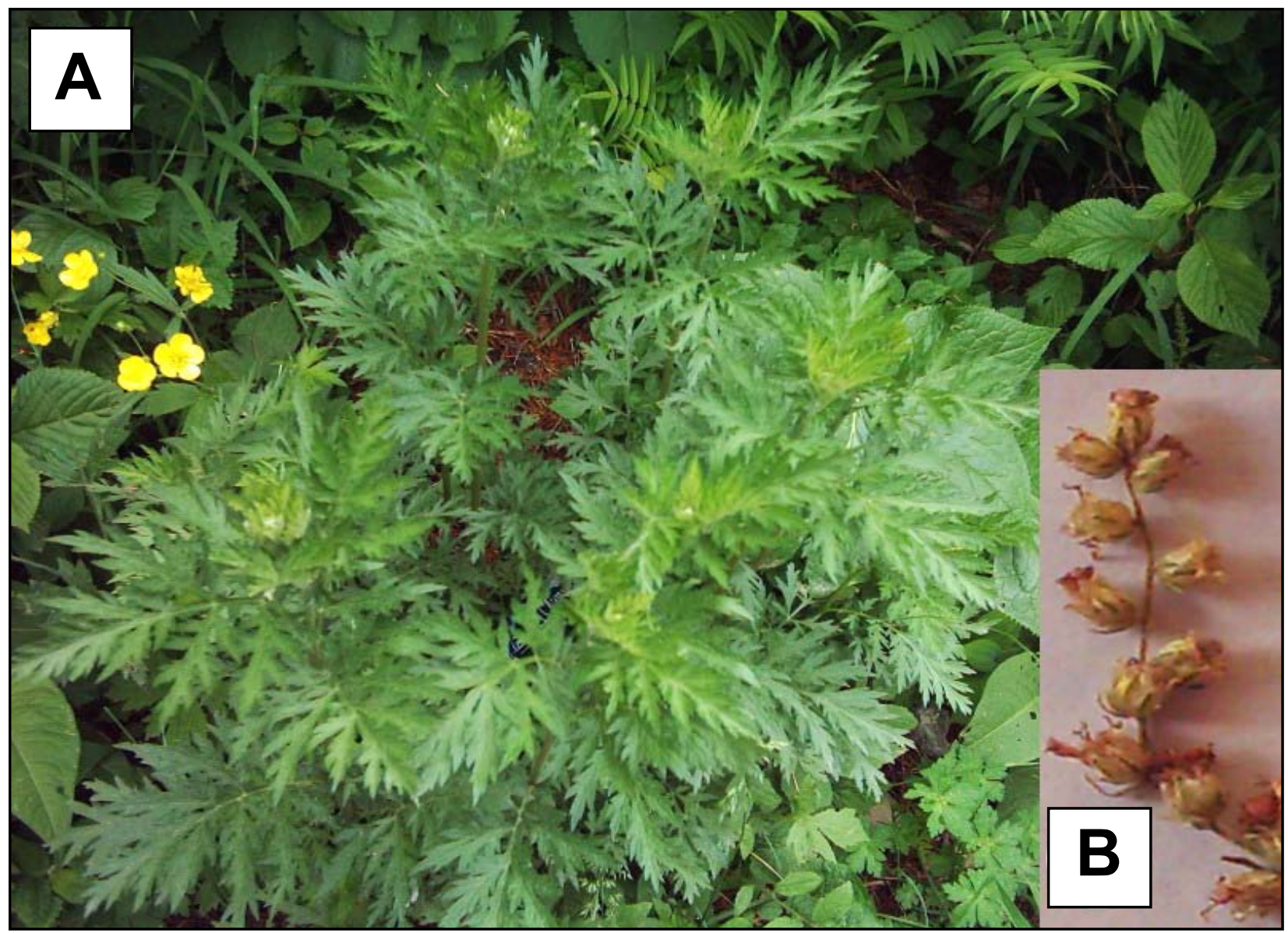

Figure 8. Artemisia dubia Wall. ex DC. (A: Young plants, B: Flowers), Pakistan. 
es are $10-25 \mathrm{~cm}$ or rarely $30 \mathrm{~cm}$ long, some time flexuous with hairs or without hairs. Lowermost leaves are ovate to oblong and 5-partite. Middle cauline leaves are ovate, $4.5-10 \mathrm{~cm} \times 4-8 \mathrm{~cm}$, abaxially densely hairy or some time glabrescent, 5-partite with elliptic to lanceolate lobes, 40$70 \mathrm{~cm} \times 8-12 \mathrm{~mm}$. Uppermost leaves are 3-partite with leafy bracts which are entire and elliptic-lanceolate to lanceolate in shape. Numerous ovoid to globose capitula in panicles, which are much branched, 1-2 $\mathrm{mm}$ in diameter with short pedicel to sessile. Ray florets are 6-8 in number and disc florets are 4-12. Cypselas are oblong to obovoid in shape.

Flowering period: August to October.

Local distribution: Found in Rawalpindi, Muzafrabad, and Ponch, from 1200 to $2000 \mathrm{~m}$ altitude.

Distribution in the world: Bhutan, China, India, Japan, Nepal, and Thailand.

Part used: Leaves.

Ethnobotanical uses:

1. Leaf powder is used for gastric problems and intestinal worms.

2. Paste of fresh leaves is applied externally for the treatment wounds and skin infections.

6. A. herba-alba Asso. (Mushki afsantheen) (Figure 9)

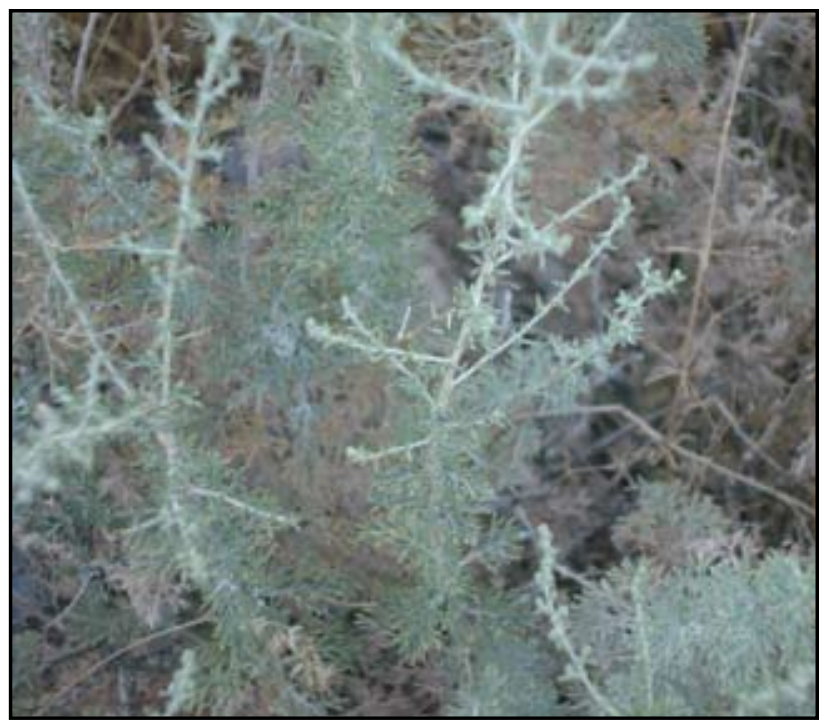

Figure 9. Artemisia herba-alba Asso., Pakistan.

Phytography: This plant is a perennial strongly aromatic grayish green herb which is 25 to $40 \mathrm{~cm}$ tall with numerous branches. Tiny stipuliform pinnatifid auricles are present at base of petioles. Basal leafs are much incised, 2-3 $X$ 1-2 mm. Oblong capitula are 3-4 mm in diameter. Florets are 2-4 in number.

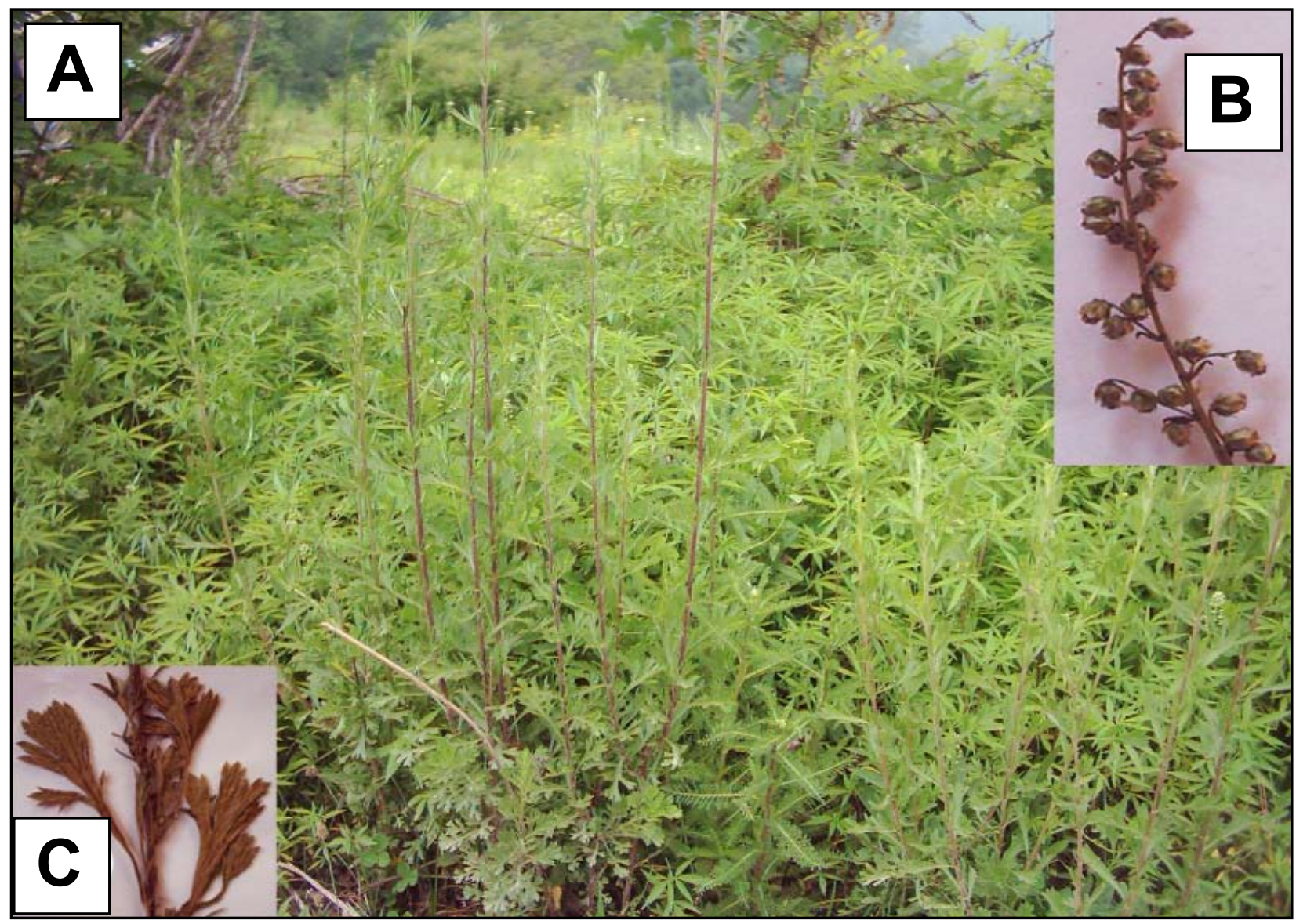

Figure 10. Artemisia japonica Thunb. in a association with Canabis sativa L. (A: Young plants, B: Flowers, C: Leaves), Pakistan. 
Flowering period: August to November.

Local distribution: Quetta.

Distribution in the world: Iran, Turkey, Middle East, and North Africa.

Part used: Whole plant.

Ethnobotanical uses:

1. Whole plant powder is used for diabetes.

2. A plant decoction is utilized for cooling purposes.

3. Fumigation with plant is used for muscular pain.

4. Dry plants are used for fire purposes.

7. A. japonica Thunb. (Kanyarts, Burmar, Basna tashang, Kharkhaliech) (Figure 10)

Phytography: This herb is perennial, $40-100 \mathrm{~cm}$ tall, strongly aromatic and glabrescent. Leaves are sessile, sparsely hairy. Basal and lowermost leaves are obovate to broadly spatulate, $3-6 \mathrm{~cm} \times 2-3 \mathrm{~cm}$. Middle leaves are 3-fid epically, 20-30 mm X 5-8 mm. Uppermost leaves are 3-cleft to entire and leafy bracts are elliptic to lanceolate. Numerous subglobose capitula are in narrow to slightly broad paniculate arrangement and 1-2 $\mathrm{mm}$ in diameter. Ray florets are 5-9 in number and disc florets are 5-10 in numbers. Cypselas are minute and obovoid in shape.

Flowering period: July to September.
Local distribution: Found in Chitral, Gilgit, Khagan, Skardu, Muzafrabad, Baltistan, Ponch, Rawalpindi, Swat and Kurram Agency from 1500 to 3500 m altitude.

Distribution in the world: Afghanistan, Bhutan, China, Japan, Korea, Laos, Myanmar, Nepal, North India, Philippines, Russia, Thailand, and Vietnam.

Part used: Stem and leaves.

Ethnobotanical uses:

1. Plant is browsed by goats and sheep.

2. A plant decoction is used against malaria.

8. A. maritima L. ex Hook.f. (Tarkh, Zoon, Rooner) (Figure 11)

Phytography: This plant is a strongly aromatic shrub with numerous erect, up to $100 \mathrm{~cm}$ tall branches. Basal and middle leaves are whitish cottony appearance, 2-2.5 X 3.5-4 cm, 2-pinnatisect, with numerous small segments, linear with obtuse apex. Upper most leaves are simple and linear in shape. Oblong to ovoid capitula, present in the axil of upper leaves forming a raceme and $10 \mathrm{~mm}$ in diameter. It contains 3-10 florets. Receptacle is without hairs. Minute cypselas are oblong to obvoid in shape. Flowering period: August to September.

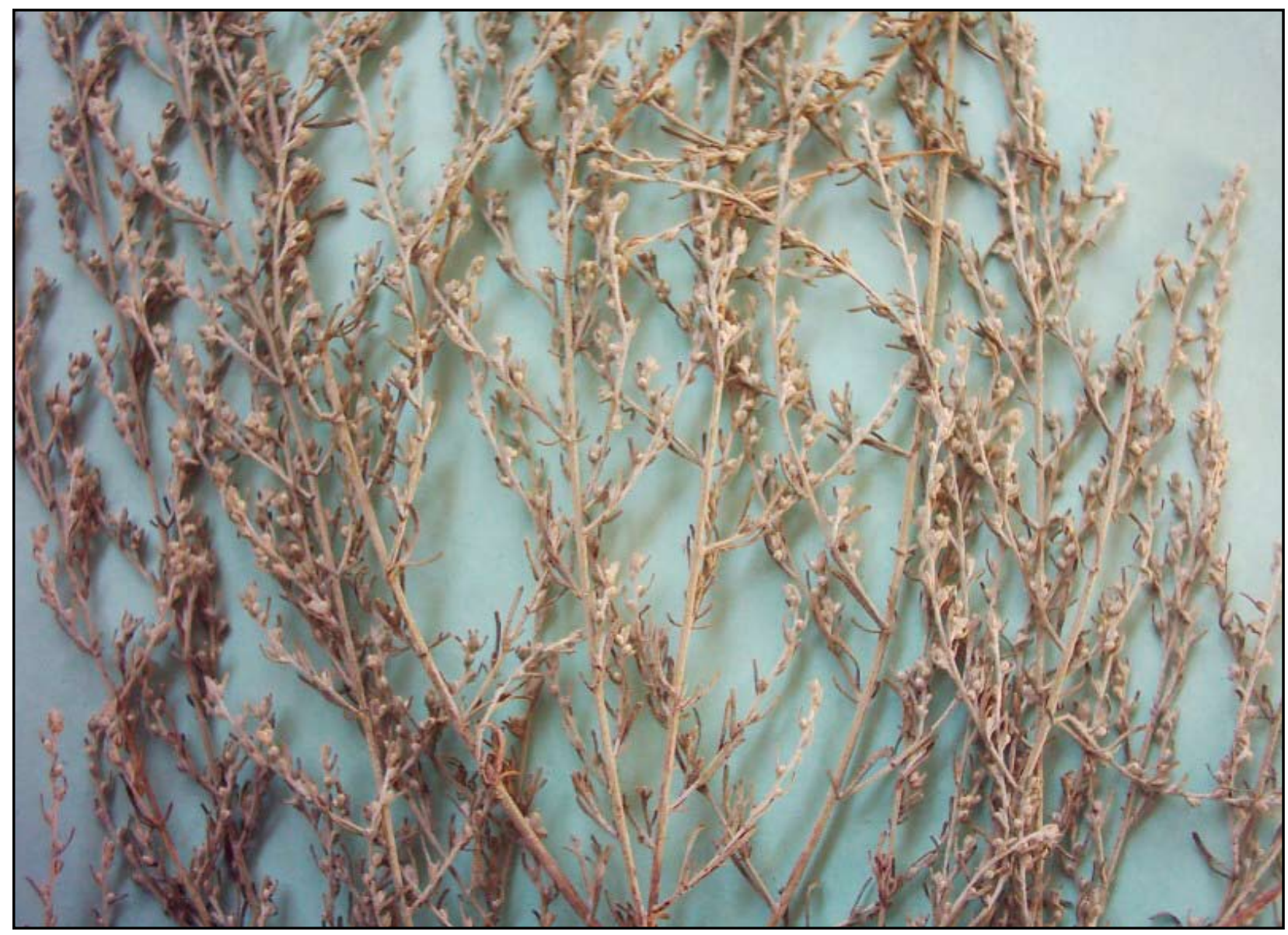

Figure 11. Artemisia maritima L. ex Hook.f., Pakistan. 
Local distribution: Found in Swat, Skardu, Chitral, Gilgit, Kurram Agency, Baltistan and Ladakh from 2000 to 4000 $m$ altitude.

Distribution in the world: Afghanistan.

Part used: Leaf and stem.

Ethnobotanical uses:

1. Plant is used as antiseptic and anti-inflammatory.

2. Leaves are utilized for cooling purposes.

3. Plant decoction is used against malaria.

4. Plant powder is used for intestinal worms.

9. A. roxburghiana Wall. ex Besser (Garrotra) (Figure 12)

Phytography: This Subshrub is $50-100 \mathrm{~cm}$ tall and densely hairy. Bifacial leaves are densely hairy beneath and whitish, upper surface is dark greenish and punctate glands are present on its both surfaces. Petioles of lowermost and middle cauline leaves are 1-3 cm long. Leaf blade is ovate to oblong-elliptic in shape, $6-10 \mathrm{~cm} \times 4-6 \mathrm{~cm}$, 2-pinnatisect. Its segments are in 2 to 3 pairs, elliptic to oblong in shape. Lateral lobes have 1-3 pairs of lobules. Lobules are lanceolate to linear-lanceolate, $0.5-1.5 \mathrm{~mm} \mathrm{X}$ 2-2.5 $\mathrm{mm}$ with narrowly winged rachis. Uppermost leaves and leafy bracts are pinnatisect with 3-4-lobes. Lobes and entire bracts are linear-lanceolate to lanceolate. Ovoid to subglobose capitula are in broad paniculate arrangement, 2-3 mm in diameter. The involucral bracts are purple and hairy. Ray florets are 4-8 in number and disc florets are 8-15 in number. Cypselas are obovoid to oblong in shape.

Flowering period: August to October.

Local distribution: Found in Rawalpindi, Islamabad, Ladakh and Kurram Agency from 2500 to $3000 \mathrm{~m}$ altitude. Distribution in the world: Afghanistan, China, India, Nepal, and Thailand.

Part used: Whole plant

Ethnobotanical uses:

1. Plant decoction is used in fever.

2. Plant powder is used for the removal of intestinal worms.

10. A. santolinifolia Turcz. ex Krasch. (Dron) (Figure 13)

Phytography: This plant is a basally woody perennial with numerous, some times very straight, up to $50 \mathrm{~cm}$ tall glabrous branches. Stems have groves. Middle leaves petiole is up to $2.5 \mathrm{~cm}$ long, articulate, leaf blade sparsely

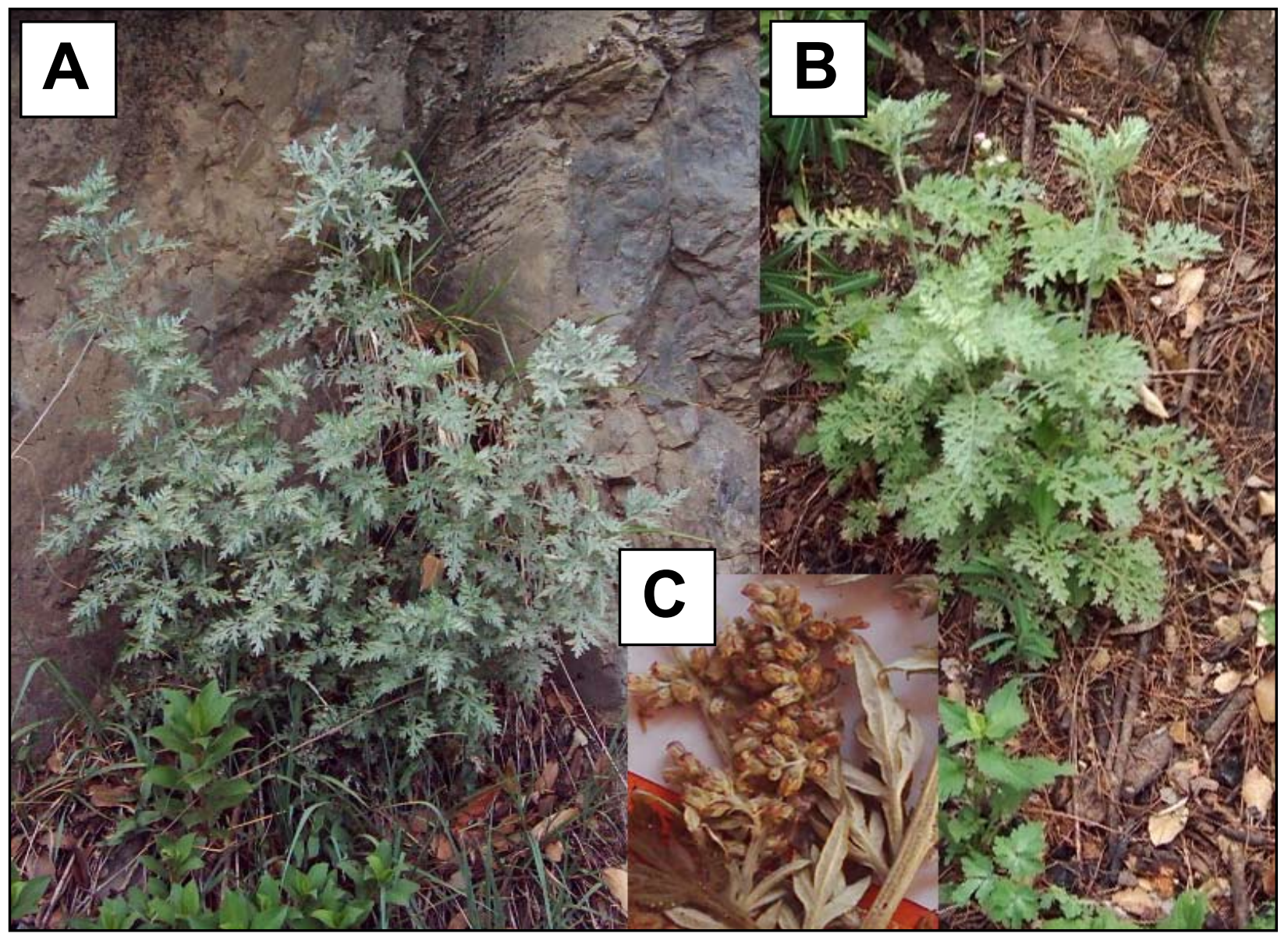

Figure 12. Artemisia roxburghiana Wall. ex Besser (A, B: Young plants in different seasons, C: Flowers), Pakistan. 


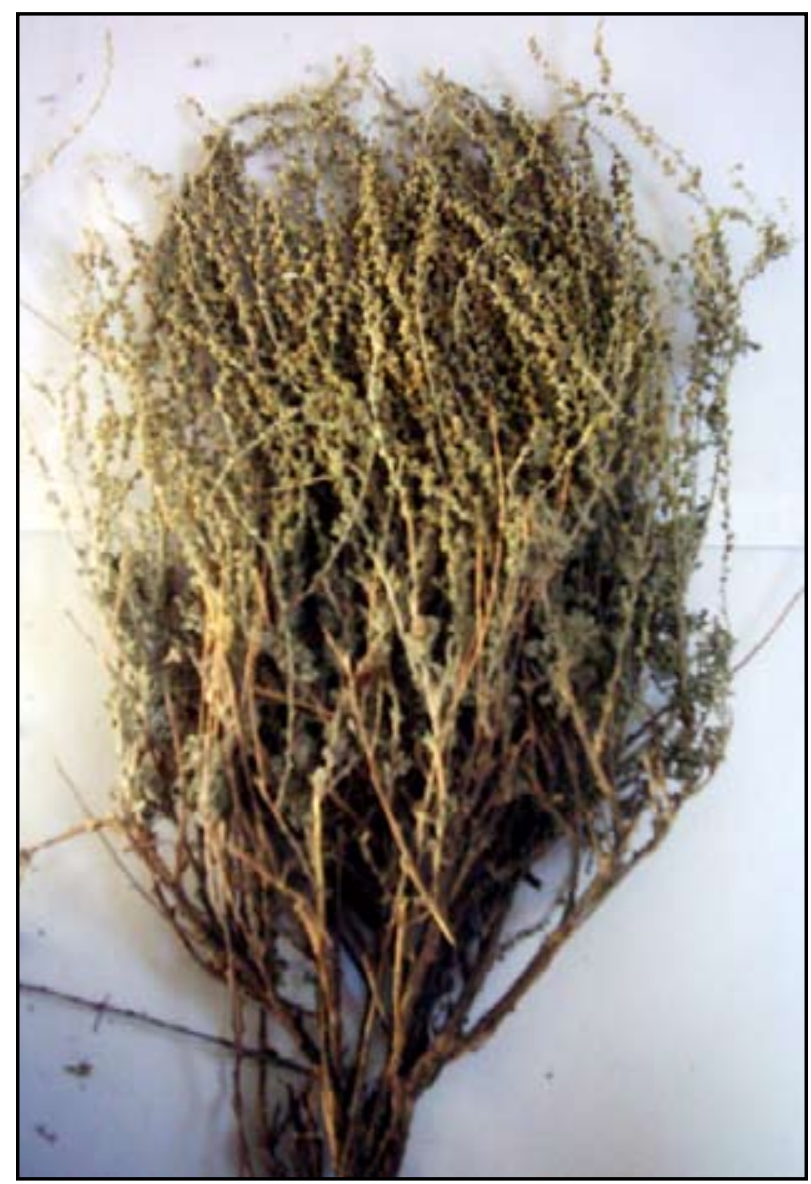

Figure 13. Artemisia santolinifolia Turcz. ex Krasch., Pakistan.

hairy to glabrous above, hairy beneath, ovate to broadly triangular-ovate, 2.5-5 X 1-3 cm. Lower leaves are 3-pinnatisect, elliptic to lanceolate in shape. They have primary segments and lobules on both sides. Uppermost leaves are 1-2-pinnatisect with segments, $1-4 \times 0.5-1 \mathrm{~mm}$, lanceolate-linear in shape with acute tips. Many globose capitula with short peduncle, 3-5 $\mathrm{mm}$ in diameter, arrange in paniculate arrangement. Involucre bracts are 3-seriate. Receptacle is convex and glabrous. Ray florets 10-12 in numbers and disc-florets are 50-60 in numbers. Cypselas are obovoid to oblong in shape.

Flowering period: July to September

Local distribution: Found in Chitral, Hunza, Ladakh, Swat, Gilgit and Baltistan, from 2500 to $3500 \mathrm{~m}$ altitude.

Distribution in the world: Afghanistan, China, India, Mongolia, and Russia.

Part used: Whole plant

Ethnobotanical uses:

1. Plant extract is used against intestinal worms.

11. A. scoparia Waldst. \& Kit. (Jhau, Lasaj, Dona, Marua, Churi-Saroj, Jaanh, Jaukay) (Figure 14)

Phytography: A very common plant which grows after rainfall in hot seasons in sandy clay soil of arid areas along

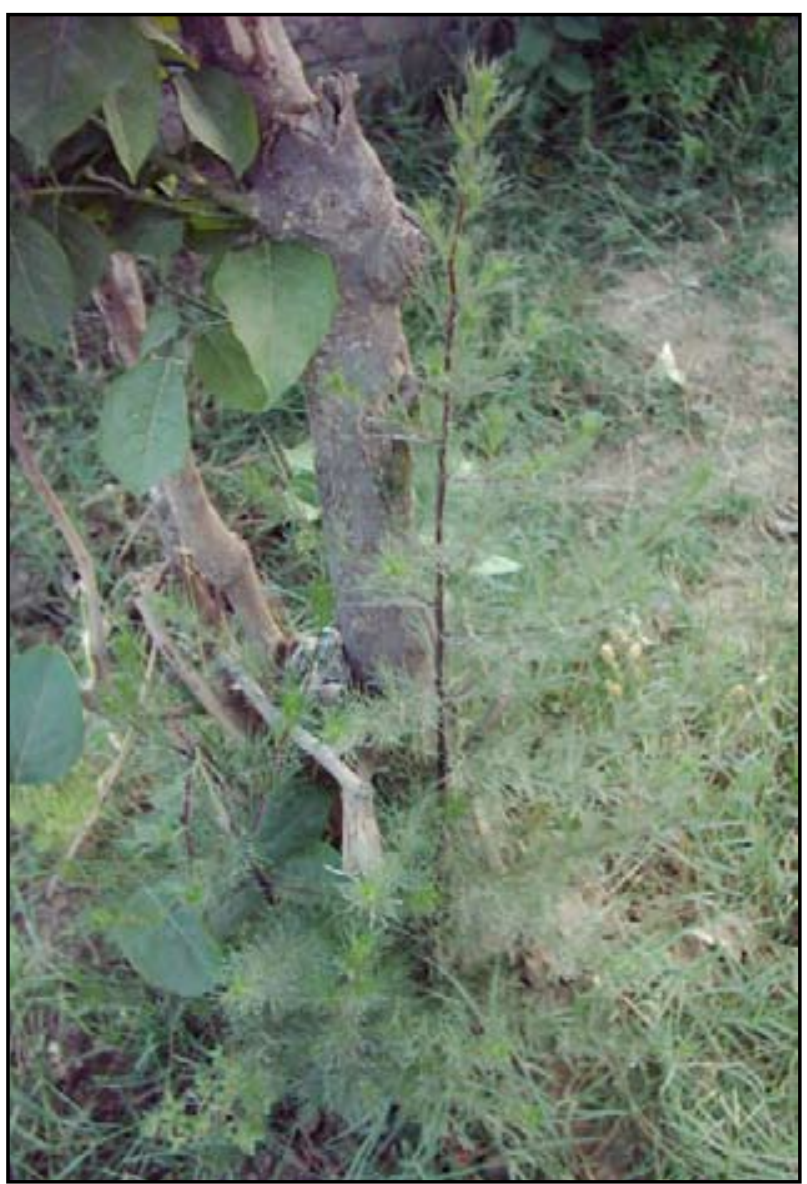

Figure 14. Artemisia scoparia Waldst. \& Kit., Pakistan.

road sides and on low hills, stony ground, waste lands, field borders and rural tracks, from 400 to $2200 \mathrm{~m}$ altitude. This herb is perennial and slightly aromatic, 40-120 $\mathrm{cm}$ high, and much branched from the lower stem. Young stem branches and leaves are sea green and when mature become yellowish. Stem often has a purple tinge. Petiole of basal leaves is $2-3 \mathrm{~cm}$ long and leaf blade is ovateoblong to elliptic, 2-4 cm X 1-3 cm and 2 to 3-pinnatisect. Segments are in 3 to 4 pairs with 1 to 2 pairs of lobules. Middle cauline leaves are sessile, oblong to ovate-oblong in shape, $15-20 \mathrm{~mm} \times 10-15 \mathrm{~mm}, 2$-pinnatisect with 2 to 3 pairs of segments. Leaf lobules are filiform, $4-8 \mathrm{~mm} \mathrm{X}$ $0.3--0.5 \mathrm{~mm}$, mostly curved. Uppermost leaves and leafy bracts are 3-4-sect. Subglobose numerous capitula are in broad paniculate arrangement, 1-2 $\mathrm{mm}$ in diameter with or without shortly pedicel. Ray florets are 5-7 in number and disc florets are 5-10 in number. Cypselas are obovoid to oblong in shape.

Flowering period: July to November.

Local distribution: Found in Gilgit, Astor, Peshawar, Swat, Malakand, Khagan, Rawalpindi, Skardu, Baltistan, Kurram, Attock, Jahelum, Quetta, Khuzdar and Kalat. Distribution in the world: Central and SW Asia (Afghanistan, Russia, Thailand), China, India, Japan, Korea, and Europe. 


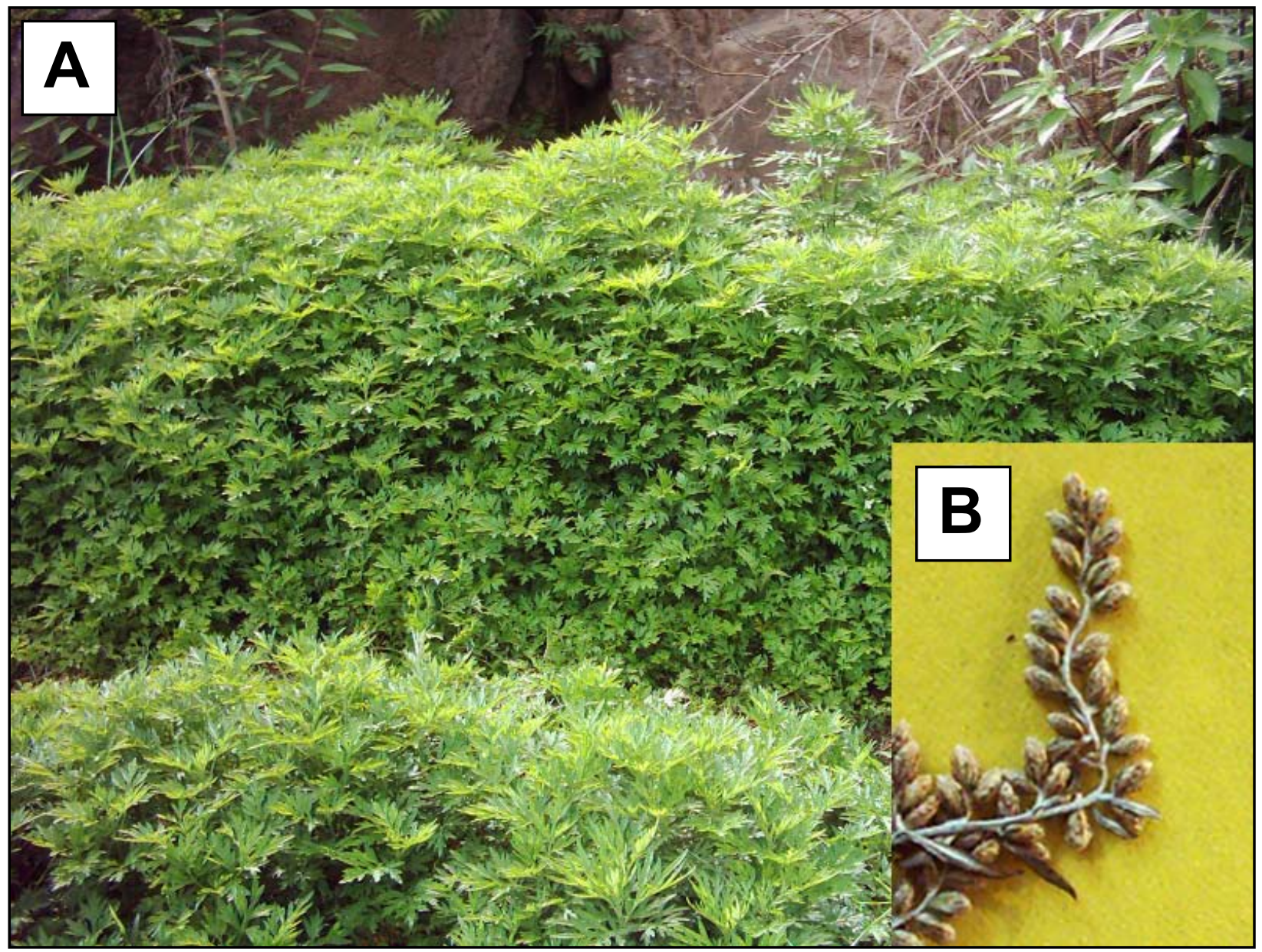

Figure 15. Artemisia vulgaris L. (A: young plants, B: Inflorescence), Pakistan.

Ethnobotanical uses:

1. Considered as fodder for goats.

2. Treats pain in the ear.

3. The smoke of twigs is considered good for burns and an infusion of it is given as a depurative.

12. A. vulgaris L. (Tatwan, Nagdowna, Tarkha) (Figure 15)

Phytography: A highly variable and extensively spreading species in which a number of subordinant taxa have been identified. This herb is perennial, $50-150 \mathrm{~cm}$ tall, and sparsely hairy. Lowermost leaves are shortly petiolate and 2-pinnatisect. Leaf blade is densely hairy beneath. Middle cauline leaves are sessile and leaf blade elliptic to ovateelliptic, $10-12 \mathrm{~cm} \times 6-10 \mathrm{~cm}$ with bipinnatisect segments which are 4 to $5 \mathrm{~cm}$ long, elliptic-lanceolate to linear-lanceolate in shape, $3-5 \mathrm{~cm} \times 1-1.5 \mathrm{~cm}$ wide, with a narrowly winged rachis. Uppermost leaves are pinnatipartite and leafy bracts are 3-lobed which are entire. Leafy bracts are lanceolate in shape. Oblong capitula are in dense narrow to broad panicles, 2-3 mm in diameter. The involucral bracts are densely hairy. Ray florets are 7-10 in numbers and disc florets 8-20 in numbers. Cypselas are obovoid to ovoid in shape.

Flowering period: August to November.

Local distribution: Found in Muzafarabad, Rawalpindi and Islamabad from 1000 to $2000 \mathrm{~m}$ altitude.

Distribution in the world: Afghanistan, India, Iran, Siberia, Turkey, Africa, Europe, and North America.

Part used: Leaves and tomentum.

Ethnobotanical uses:

1. A leaf infusion is used in fever.

2. The tomentum is used as moxa.

\section{Discussion}

The genus Artemisia has a therapeutic history reaching back over two millennia (Zinczuk et al. 2007) and it is widely used in folk remedies (Negahban et al. 2007). In Pakistan, the use of Artemisia based folk remedies is also common practice in the studied localities. Uses of these Artemisia species, for the treatment of various medicinal problems along with the other uses by the local inhabitants were passed down from generation to generation but 


\section{Hayat et al. - Ethnobotany of the Genus Artemisia L. (Asteraceae) in Pakistan 159}

rapid cultural transformation is causing old traditions to become extinct (Hayat et al. 2008).

We have recorded some common human ailments (diabetes, gastric problems, intestinal worms, skin infections, thorax illness) that have been treated using Artemisia. Most of the Artemisia species, which were studied, are widely used in the other parts of the world in similar or different ways. For example, A. dubia leaf juice is used in Madhupur, Tangail, Bangladesh for the treatment of leprosy and in preparation of a fermenting medium for their traditional liquor (Anisuzzaman et al. 2007). Similarly, A. dubia whole plant is utilized in Magar of Bukini, Baglung, Western Nepal for stomachic, purgative, hysteria asthma, skin diseases like scabies and on ulcers (Sapkota 2008). Iriadam et al. (2006) reported that $A$. herba-alba possess antidiabetic effects. It was also found that Artemisia species have been used in many countries of the Middle East and Turkey as treatments of diabetes, high blood pressure and gastrointestinal ailments. Additional properties of some of the Artemisia are supported by scientific findings such as: fumigant toxicity of $A$. scoparia (Negahban et al. 2004, Negahban \& Moharramipour 2005); antimalarial activity of $A$. japonica, A. maritima and Artemisia nilagirica (C.B. Clarke) Pamp. (Valecha et al. 1994), Artemisia indica Willd. (Chanphen et al. 1998), and $A$. annua (Duke et al. 1994); selective killing of human breast cancer cells by artemisinin from $A$. annua (Singh \& Lai 2001); and anthelmintic activity of $A$. brevifolia in sheep (lqbal et al. 2004). Many of the Artemisia identified in this study (e.g., A. absinthium, A. annua, A. dubia, A. herba-alba and A. maritima) are part of traditional ethnobotanical knowledge of many countries and marketed internationally.

Our study results confirm other studies in these same areas of Pakistan. Ibrar et al. (2007) investigated the knowledge of use of Artemisia species by the indigenous people in the Ranyan hills Shangla District of Pakistan. Hayat et al. (2008) reported $A$. scoparia as a purgative and also used to treat burns in Tehsil Pindigheb, (Attock District) Pakistan. Gilani et al. (2003) found A. brevifolia as anthelmintic and also used for stomach problems in Kurram Agency, Pakistan. Aziz (1996) recorded that $A$. maritima is used against abdominal pain, fever and intestinal worms in Chitral valley. Artemisia parviflora Roxb. ex D.Don (now $A$. japonica) and $A$. santolinifolia are described as therapeutic plants of Booni valley of district Chitral, Pakistan (Ahmed et al. 2006). Qurashi et al. (2006) reported $A$. absinthium and $A$. maritima as medicinal plants of Gilgit. Khan et al. (2003) discussed the ethnobotanical uses of A. scoparia and A. vulgaris. Mannan et al. (2008) reported A. dubia as a source of artemisinin, which is used as an antimalarial drug. Sardar and Khan (2009) found $A$. annua as a treatment for jaundice, fever and as a blood purifier. Hussain et al. (2006) observed the ethnobotanical uses of $A$. scoparia. Khan and Khatoon (2008) collected ethnobotanical observations of $A$. absinthium, A. brevifolia and $A$. scoparia. However, our research also unveiled some new aspects of Artemisia based therapies. For example, $A$. scoparia is used for thorax illness.

This research also indicates that inhabitants of the studied localities were not using Artemisia species against modern day ailments like cancer, HIV-AIDS, etc. This is a sign of the disappearance of ethnobotanical knowledge because local people were practicing what they inherited from their forefathers as a remnant of earlier information. There is no expectation that people will use this acquaintance in the future to develop new remedies even in remote localities.

The economics of Artemisia species have been previously investigated. Gilani et al. (2003) reported on the economic importance of $A$. brevifolia in Pakistan. Zaidi (1996) investigated the market value of $A$. maritima. Anderson (1988) identified $A$. absinthium, $A$. maritima and $A$. vulgaris as economically important medicinal plants of Pakistan. Rauf et al. (2007) investigated the status, utilization and trade of Hazara (Northern Pakistan) areas healing plants including Artemisia species. But many other Artemisia species of commercial potential still exist as wild plants in different regions of the country. Therefore, they need proper attention in the future for both evaluation of conservation management and development of commercialization strategies. Many Artemisia species are becoming threatened (e.g., A. amygdalina Decne. in Kashmir) or may be threatened in the near future due to eco-environmental changes (Dar et al. 2006). Similarly, Khan (2004) discussing six Artemisia species and their potential, constraints in their conservation, and future prospects. There is an immediate need to adopt a proper conservation strategy for protection of this medicinal plant resource for future generations.

\section{Conclusion}

Our study revels that genus Artemisia species possess therapeutic potential and are still part of culture of Pakistan. Conservation and study of Artemisia plants at biochemical levels are called for to provide a significant contribution to pharmacology industry and economy of the nation. Results of this ethnobotanical survey can provide bases for such projects.

\section{Acknowledgements}

We are thankful to Dr. Rizwana Aleem Qurashi for her Technical facilitation. We are also thankful to Dr. M. Tahir Shah for his constructive comments on manuscript. We also acknowledge Higher Education Commission (HEC) Pakistan for their financial assistance.

\section{Literature Cited}

Ahmed, S., A. Ali, H. Beg, A.A. Dasti \& Z.K. Shinwari. 2006. Ethnobotanical studies on some medicinal plants of 
Booni valley, District Chitral Pakistan. Pakistan Journal of Weed Science Research 12(3):183-190.

Anderson, J.W. 1988. Medicinal plants in Pakistan in Unani Materia Medica. Hamdarad Medicus 31(4):61-83.

Anisuzzaman, M., A.H.M.M. Rahman, M. Harun-orRashid, A.T.M. Naderuzzaman \& A.K.M.R. Islam. 2007. An ethnobotanical study of Madhupur, Tangail. Journal of Applied Sciences Research 3(7):519-530.

Aziz, A. 1996. Indigenous knowledge of plant uses and ethnobotany of Chitral with particular reference to medicinal plants. Proceedings of the Ethnobotany Workshop. National Agriculture Research Center, Islamabad.

Bremer, K. \& C.J. Humphries. 1993. Generic Monograph of the Asteraceae-Anthemideae. Bulletin of the Natural History Museum of London (Botany) 23:71-177.

Bridges K.W. \& Lau, Y.H. 2006. The skill acquisition process relative to ethnobotanical methods. Ethnobotany Research \& Applications 4:115-118.

Chanphen, R., Y. Thebtaranonth, S. Wanauppathamkul \& Y. Yuthavong. 1998. Journal of Natural Products 61(9):1146-1147.

Dar, A.R., G.H. Dar \& Z. Reshi. 2006. Conservation of Artemisia amygdalina - A critically endangered endemic plant species of Kashmir Himalaya. Endangered Species Update 23:34-39.

Duke, M.V., R.N. Paul, H.N. Elsohly, G. Sturtz \& S.O. Duke. 1994. Localization of artemisinin and artemisitene in foliar tissues of glanded and glandless biotypes of $A r-$ temisia annua L. International Journal of Plant Sciences 155:365-372.

El-Moslimany, A.P. 1990. Ecological significance of common non-arboreal pollen: Examples from dry lands of the Middle East. Review of Palaeobotany and Palynology 64:343-350.

Erdtman, G. 1969. Hand Book of Palynology: Morphology, taxonomy, ecology. Munksgaard, Copenhagen.

Ghafoor, A. 2002. Asteraceae (I)-Anthemideae. Pp. 93161 in Flora of Pakistan. Edited by S.I. Ali \& M. Qaiser. Missouri Botanical Garden, St. Louis, Missouri.

Gilani, S.S., S.Q. Abbas, Z.K. Shinwari, F. Hussain \& K. Nargis. 2003. Ethnobotanical studies of Kurram Agency, Pakistan through rural community participation. Pakistan Journal of Biological Sciences 6(15):1368-1375.

Hayat, M.Q., M.A. Khan, M. Ahmad, N. Shaheen, G.Yasmin \& S. Akhter. 2008. Ethnotaxonomical approach in the identification of useful medicinal flora of Tehsil Pin- digheb (District Attock) Pakistan. Ethnobotany Research \& Applications 6:35-62.

Hussain, F., I. Iqbal \& M.J. Durrani. 2006. Ethnobotany of Ghalegay, District Sawat, Pakistan. Acta Botanica Yunnanica 28(3):305-314.

Ibrar, M., F. Hussain \& A. Sultan. 2007. Ethnobotanical studies of plant resources of Ranyal Hills, District Shangla, Pakistan. Pakistan Journal of Botany 39(2):329-337.

Iqbal, Z., M. Lateef, M. Ashraf \& A. Jabbar. 2004. Anthelmintic activity of Artemisia brevifolia in sheep. Journal of Ethnopharmacology 93:265-268.

Iradam, M., D. Musa, H. Gumusan \& F. Baba. 2006. Effects of two Turkish medicinal plants Artemisia herba-alba and Teucrium polium on blood glucose levels and other biochemical parameters in rabbits. Journal of Cell and Molecular Biology 5:19-24.

Jain, S.K. 1967. Ethnobotany: Its scope and study. Indian Museum Bulletin 2:39-43.

Khan, A., S.S. Gilani, F. Hussain \& M.J. Durrani. 2003. Ethnobotany of Gokand valley, District Bunner, Pakistan. Pakistan Journal of Botany 6(4):363-369.

Khan, M.I. 2004. Astore, a hub of medicinal plants in Northern Areas of Pakistan (Present potentials, constrains in conservation and future prospects). Survey of Medicinal Plants in Northern Areas of Pakistan. www.wwfpak.org/ nap/dnap_medicinalplants_survey_na_ibrahim.php

Khan, S.W. \& S. Khatoon. 2008. Ethnobotanical studies on some useful herbs of Haramosh and Bugrote valleys in Gilgit, Northern Areas of Pakistan. Pakistan Journal of Botany 40(1):43-48.

Ling, Y.R. 1982. On the system of genus Artemisia L. and the relationship with its allies. Bulletin of the Botanical Laboratory of the North-Eastern Forestry Institute 2:1-60.

Ling, Y.R. 1991a. The old world Seriphidium (Compositae). Bulletin of the Botanical Laboratory of the NorthEastern Forestry Institute 11:1-40.

Ling, Y.R. 1991b. The old world Artemisia (Compositae). Bulletin of the Botanical Laboratory of the North-Eastern Forestry Institute 12:1-10.

Ling, Y.R. 1994. The genera Artemisia L. and Seriphidium (Bess.) Poljak. in the world. Compositae Newsletter 25:39-45.

Ling, Y.R. 1995a. The new world Artemisia L. Pp. 255-281 in Advances in Compositae Systematics. Edited by D.J.N. Hind, C. Jeffrey \& G.V. Pope. Royal Botanical Garden, Kew, UK. 


\section{Hayat et al. - Ethnobotany of the Genus Artemisia L. (Asteraceae) in Pakistan 161}

Ling, Y.R. 1995b. The new world Seriphidium (Besser) Fourr. L. Pp. 283-291 in Advances in Compositae Systematics. Edited by D.J.N. Hind, C. Jeffrey \& G.V. Pope. Royal Botanical Garden, Kew, UK.

Mabberley, D.J. 1990. The Plant Book. 2nd Edition, Cambridge University Press, Cambridge.

Mannan, A., N. Shaheen, W. Arshad, R.A. Qureshi, M. Zia \& B. Mirza. 2008. Hairy roots induction and artemisinin analysis in Artemisia dubia and Artemisia indica. African Journal of Biotechnology 7(18):3288-3292.

Martin G.J. 2004. Ethnobotany: A methods manual. Earthscan Publications Ltd., London.

McArthur, E.D. 1979. Sagebrush systematics and evolution. Pp. 14-22 in Sagebrush Ecosystem Symposium. Utah State University, Logan.

McArthur, E.D. \& A. Plummer. 1978. Biogeography and management of the native western shrubs: A case study, section Tridentatae of Artemisia. Great Basin Naturalist 2:229-243.

Nasir, Y.J. \& R.A. Rafiq. 1995. Wild Flowers of Pakistan. Edited by R.J. Robert. Oxford University Press, Karachi, Pakistan.

Negahban, M. \& S. Moharramipour. 2005. Fumigant toxicity of essential oil from Artemisia scoparia Waldst and Kit against Sitophilus oryzae (Coleoptera: Curculionidae). Pp. 124 in Proceedings of the Second Symposium of Medicinal Plants, 26-27 January 2005, Tehran, Iran. Edited by Secretariat of the Symposium, Faculty of Agriculture, University of Shahed. Shadnaghsh Printing House, Tehran, Iran.

Negahban, M., S. Moharramipour \& F. Sefidkon. 2007. Fumigant toxicity of essential oil from Artemisia sieberi Besser against three stored-product insects. Journal of Stored Products Research 43:123-128.

Negahban, M., S. Moharramipour \& M. Yousefelahi. 2004. Efficacy of essential oil from Artemisia scoparia Waldst and Kit against Tribolium castaneum (Herbst) (Coleoptera: Tenebrionidae). Pp. 53 in Proceedings of the Fourth International Iran and Russia Conference on Agriculture and Natural Resources, 8-10 September 2004, Shahrekord, Iran. Edited by S.J. Sadatinejad, S. Mohammadi, A. Soltani \& A. Ranjbar. Dadyar Publisher, Shahrekord, Iran.

Oberprieler, C. 2001. Phylogenetic relationships in Anthemis L. (Compositae, Anthemideae) based on nrDNA ITS and cpDNA trnL/trnF IGS sequence variation. Plant Systematics and Evolution 255:145-170.
Pareto, G. 1985. Artemisia. Ricerca ed applicazione. Quaderni di 'Piemonte Agricoltura', supplemento 2:1261.

Qureshi, R.A., M.A. Ghufran, K.N. Sultana, M. Ashruf \& A.G. Khan. 2006. Ethnobotanical studies of medicinal plants of Gilgit District and surrounding areas. Ethnobotany Research \& Application 5:115-122.

Rauf, A., M.K. Baloch, F.M. Abbasi, M.R. Chattha \& T.Z. Mahmod. 2007. Status, utilization and trade of Hazara areas healing plants of Pakistan. Journal of Food, Agriculture \& Environment 5(2):236-242.

Sapkota, P.P. 2008. Ethno-ecological observation of Magar of Bukini, Baglung, Western, Nepal. Dhulagiri Journal of Sociology and Anthropology 2:227-252.

Sardar, A.A. \& Z.U.D. Khan. 2009. Ethnomedicinal studies on plant resources of tehsil shakargarh, district narowal, Pakistan. Pakistan Journal of Botany 41(1):11-18.

Shinwari, M. I. \& M.A. Khan. 2000. Folk use of medicinal herbs of Margalla Hills National Park, Islamabad. Journal of Ethnopharmacology 69:45-56.

Shultz, L.M. 2006. Artemisia L. Pp. 503-534 in Flora of the North America North of Mexico. Volume 19. Edited by the Flora of the North America Editorial Committee. Oxford University Press, New York.

Singh, N. \& H. Lai. 2001. Selective toxicity of dihydroartemisinin and holotransferin towards human breast cancer cells. Life Sciences 70:49-56.

Sterwart, R.R. 1972. An annotated catalogue of the vascular plants of West Pakistan and Kashmir. Pp. 93-161 in Flora of West Pakistan. Edited by S.I. Ali \& M. Nasir. Fakhri Printing Press Karachi, Pakistan.

Tan, R.X., W.F. Zheng \& H.Q. Tang. 1998. Biologically active substances from the genus Artemisia. Planta Medica 64:295-302.

Trotter, T. 1981. Folk remedies as indicators of common illness: Example from US-Mexico border. Journal of Ethnopharmacolocy 4:207-221.

Tutin, T.G., K. Persson \& W. Gutermann. 1976. Artemisia L. Pp. 178-186 in Flora Europaea. Volume 4. Edited by T.G. Tutin, V.H. Heywood, N.A. Burges, D.M. Moore, D.H. Valentine, S.M. Walters \& D.A. Webb. Cambridge University Press, Cambridge.

Valecha, N., S. Biswas, V. Badoni, K.S. Bhandari \& O.P. Sati. 1994. Antimalarial activity of Artemisia japonica, Artemisia maritima and Artemisia nilegarica. Indian Journal of Pharmacology 26:144-146. 
Valles, J. \& E.D. McArthur. 2001. Artemisia systematics and phylogeny: Cytogenetic and molecular insights. $\mathrm{Pp}$ 67-74 in Shrubland Ecosystem Genetics and Biodiversity. Edited by E.D. McArthur \& D.J. Fairbanks. Proceedings of June 13-15, 2000, Provo, Utah. US Department of Agriculture, Rocky Mountain Research Station, Ogden.

Valles, J. \& T. Garnatje. 2005. Artemisia and its allies: genome organization and evolution and their biosystametic, taxonomical and phylogenetic implications in Artemisiinae and related subtribes (Asteraceae, Anthemideae). Pp. 255-285 in Plant Genome: Biodiversity and Evolution. Volume 1B, Phanerogams. Edited by A. Sharma. Science Publishers, Enfield, New Hampshire.

Valles, J., M. Torrell, T. Garnatje, N. Garcia-Jacas, R. Vilatersana \& A. Susanna. 2003. Genus Artemisia and its al- lies, phylogeny of the subtribe Artemisiinae (Asteraceae, Anthemadea) based on nucleotide sequences of nuclear ribosomal DNA internal transcribed spacers (ITS). Plant Biology 5:274-284.

Vogl, C.R., B.V. Lukasser \& R.K. Purl. 2004. Tools and Methods for Data Collection in Ethnobotanical Studies of Homegardens. Field Methods 16(3):285-306.

Zaidi, S.H. 1996. Quarterly Progress Report on "Medicinal Plant Survey" under 'Biodiversity Project' of IUCN. Islamabad, Pakistan.

Zinczuk, J., A.E.A. Ruveda, H.W. Thompson \& R.A. Lalancette. 2007. (+)- Santonide, a sesquiterpenoid enol lactone derived from Artemisia. Acta crystallographica Section E 63:1490-1491. 